\title{
Striatisporolide A, a butenolide metabolite from Athyrium multidentatum (Doll.) Ching, as a potential antibacterial agent
}

\author{
JI-WEN SHENG，DONG-MEI LIU，LIANG JING，GUI-XUE XIA，WEI-FEN ZHANG, \\ JING-RU JIANG and JIN-BAO TANG
}

Department of Pharmacy, Weifang Medical University, Weifang, Shandong 261053, P.R. China

Received September 19, 2018; Accepted March 21, 2019

DOI: $10.3892 / \mathrm{mmr} .2019 .10244$

\begin{abstract}
The present study aimed to investigate the antibacterial activity of striatisporolide A (SA) against Escherichia coli (E. coli) and the underlying mechanism. Antibacterial activity was evaluated according to the inhibitory rate and zone of inhibition. The antibacterial mechanism was investigated by analyzing alkaline phosphatase (AKP) activity and ATP leakage, protein expression, cell morphology and intracellular alterations in $E$. coli. The results demonstrated that SA exerted bacteriostatic effects on E. coli in vitro. AKP activity and ATP leakage analysis revealed that SA damaged the cell wall and cell membrane of $E$. coli. SDS-PAGE analysis indicated that SA notably altered the level of 10 and $35 \mathrm{kDa}$ proteins. Scanning electron microscopy and transmission electron microscopy analyses revealed marked alterations in the morphology and ultrastructure of E. coli following treatment with SA. The mechanism underlying the antimicrobial effects of SA against $E$. coli may be attributed to its actions of disrupting the cell membrane and cell wall and regulation of protein level. The findings of the present study provide novel insight into the antimicrobial activity of SA as a potential natural antibacterial agent.
\end{abstract}

\section{Introduction}

Microbial contamination is a global issue associated with illnesses caused by the ingestion of food contaminated with mycotoxins, which have adverse effects on humans, animals and crops (1). Additionally, multi-drug-resistant pathogens, including strains of Escherichia coli, Staphylococcus aureus

Correspondence to: Dr Dong-Mei Liu or Professor Wei-Fen Zhang, Department of Pharmacy, Weifang Medical University, 7166 Baotong West Street, Weifang, Shandong 261053, P.R. China

E-mail:1dmwfmc@163.com

E-mail: zwf2024@126.com

Key words: striatisporolide A, antibacterial activity, Escherichia coli, antibacterial mechanism, electron microscope and Candida albicans, have been reported to arise from the increased use of antibiotics in recent years (2). A report on the antimicrobial susceptibility profile revealed that $E$. coli showed high rates of resistance to commonly used antibiotics, such as ampicillin and septrin, and relatively lower resistance rates to amoxicillin/clavulanate, chloramphenicol, ciprofloxacin, gentamicin, nitrofurantoin and ceftriaxone (3). Annually, numerous mortalities have been caused by infection with these 'superbugs' worldwide; such infection has become one of the most important problems affecting public health $(4,5)$. Certain synthetic antimicrobial compounds, including nitrites, sulfites and butylated hydroxyanisole, are commonly used in processed foods; however, with safety concerns, considerable interest has arisen in identifying alternative natural antimicrobial agents (6). Plant extracts, including esters, peptides and phenolics, may be sources of natural antimicrobial molecules with potential to eliminate antibiotic-resistant microorganisms. Nisin, a non-toxic natural preservative from lactic acid bacteria strains, is used in the food industry worldwide (7). Numerous mechanisms are involved in the antimicrobial actions of these natural molecules, including damaging the cell membrane and/or cell wall, and inhibiting the synthesis of intracellular substances, including DNA, proteins and enzymes.

Athyrium multidentatum (Doll.) Ching (AMC) belongs to the Athyriaceae family and grows in shady and damp environments, including mountains and forests. It is usually used for treating parasitic infections, anxiety and arthritis in the Changbai Mountains region of China (8); AMC is also a nutritious potherb. The rhizome of AMC is rich in numerous nutritional components, including amino acids, starch and polysaccharides. In our previous study, striatisporolide A (SA) was extracted from the rhizomes of AMC (9). SA is regarded as a butenolide derivative due to its four-carbon heterocyclic ring skeleton of $2(3 \mathrm{H})$ furanone. This compound is produced by few types of fungi and bacterial strains $(10,11)$. Studies have demonstrated that SA exerted a weak cytotoxic effect on A549 cells, but exhibited notable cytoprotective activity on human umbilical vein endothelial cells $(11,12)$; the antibacterial activity of SA requires further investigation.

The purpose of this study was to investigate the antibacterial activity of SA and the underlying mechanism. On the basis of our preliminary experiments, the present study selected 
E. coli ATCC 8739 as the experimental strain for analysis. The antibacterial potential of SA was determined according to the rate and zone of inhibition. The abundance of alkaline phosphatase (AKP) and ATP was detected to assess the effects of SA on the cell wall and membrane of E. coli ATCC 8739. The effects of SA on protein expression, bacterial morphology and intracellular structure of $E$. coli were also determined to investigate the underlying mechanisms.

\section{Materials and methods}

Materials. Tryptic soy broth (TSB) was purchased from Hope Bio-Technology Co., Ltd.; 2,3,5-triphenyltetrazolium chloride (TTC), a bicinchoninic acid (BCA) protein assay kit, a pre-stained protein ladder (11-180 kDa), PBS and DMSO $(\geq 99.5 \%)$ were obtained from Beijing Solarbio Science \& Technology Co., Ltd. Luria-Bertani (LB) broth, AKP, ATP and the SDS-PAGE gel quick preparation kit were obtained from Beyotime Institute of Biotechnology. Agar was purchased from neoFroxx $\mathrm{GmbH}$. Ciprofloxacin hydrochloride $(\mathrm{CX})$ was acquired from Jingxin Pharmaceutical Co., Ltd. AMC rhizomes were harvested in the Changbai Mountain area of China in 2017 and stored in a dry and ventilated room.

Preparation of samples. SA was extracted from the rhizomes of AMC as described previously (9). Briefly, the ground AMC rhizomes were immersed in methanol at room temperature for 20 days twice, then filtered. The resultant leach liquor was concentrated under reduced pressure, and successively separated with petroleum ether and ethyl acetate. The ethyl acetate extract was subjected to silica gel-column chromatography and eluted with petroleum ether/ethyl acetate $(4: 1, \mathrm{v} / \mathrm{v})$ to obtain SA. Finally, the purified SA was dissolved in DMSO and filtered with a $0.22-\mu \mathrm{m}$ bacteriological filter. CX was used as the positive control. CX was dissolved in normal saline for $10 \mathrm{~min}$ via sonication and filtered with a $0.22-\mu \mathrm{m}$ bacteriological filter. All samples were stored at $4^{\circ} \mathrm{C}$ for the following assays.

Bacterial cultures. The standard strain of E. coli (Migula) Castellani and Chalmers (cat. no. ATCC 8739) was procured from Beijing Zhongyuan Ltd., which was maintained on an LB agar plate supplemented with $1.5 \%$ agar, $1 \%$ peptone, $0.5 \%$ yeast extract and $1 \%$ sodium chloride at $4^{\circ} \mathrm{C}$, and subcultured once a month. The bacteria were maintained in TSB medium on a rotary shaker at $120 \mathrm{rpm}$ and $35^{\circ} \mathrm{C}$ for $14 \mathrm{~h}$ until the mid-log phase of growth was achieved. The turbidity of the cell suspensions was measured at $600 \mathrm{~nm}$ using a microplate reader (Spectramax M5; Molecular Devices, LLC, Sunnyvale, CA, USA) and adjusted to the required concentrations of $1 \times 10^{6}$ or $1 \times 10^{8}$ colony-forming units (CFU)/ml using a McFarland standard prior to analysis in the subsequent experiments.

Determination of antibacterial activity of $S A$. The antibacterial activity of SA was determined by TTC and Kirby-Bauer disc agar diffusion assays. E. coli was incubated in TSB for $20 \mathrm{~h}$ at $35^{\circ} \mathrm{C}$. The rate of growth inhibition was determined by a modified TTC assay (13). E. coli was diluted to $1 \times 10^{8} \mathrm{CFU} / \mathrm{ml}$ with fresh TSB; $50 \mu \mathrm{l}$ bacterial suspension was added to each well of a sterile 96-well microplate. Then, $50 \mu \mathrm{l} \mathrm{SA}(25-400 \mu \mathrm{M})$ was added. The bacterial suspension incubated without SA served as the normal control and TSB was used as the blank control. Following culturing for $24 \mathrm{~h}$ at $35^{\circ} \mathrm{C}$, the suspension was mixed with $15 \mu \mathrm{lTC}$ reagent $(5 \mathrm{mg} / \mathrm{ml})$ and incubated for another $2 \mathrm{~h}$. Subsequently, $50 \mu \mathrm{l}$ DMSO was added and bacteria were gently agitated for $10 \mathrm{~min}$ at $25^{\circ} \mathrm{C}$ to dissolve the red triphenyl formazan crystals. The optical density (OD) was measured at $532 \mathrm{~nm}$ using a microplate reader (Thermo Fisher Scientific, Inc.). The antibacterial activity of SA was expressed as a percentage of inhibition and calculated according to the following formula: Inhibition rate $(\%)=\left(\mathrm{OD}_{\text {sample } 532}-\mathrm{OD}_{\text {blank } 532}\right) /$ $\left(\mathrm{OD}_{\text {normal } 532}-\mathrm{OD}_{\text {blank 532 }}\right) \times 100$.

The antibacterial activity of SA was investigated using a Kirby-Bauer disc agar diffusion assay; 200 or $400 \mu \mathrm{M}$ of SA were applied for analysis. In brief, E. coli was diluted to $1 \times 10^{6} \mathrm{CFU} / \mathrm{ml}$ with fresh TSB and evenly propagated over the surface of an LB agar plate. Sterile filter paper $(6 \mathrm{~mm})$ pre-soaked with 200 or $400 \mu \mathrm{M} \mathrm{SA}$ was applied to the plate and incubated for $20 \mathrm{~h}$ at $35^{\circ} \mathrm{C}$. The sensitivity of E. coli to SA was determined according to the diameter of the inhibition zone: A diameter of $\geq 15 \mathrm{~mm}$ was considered to indicate high sensitivity to SA; $10-15 \mathrm{~mm}$ indicated moderate sensitivity and a diameter of $\leq 10 \mathrm{~mm}$ suggested low sensitivity to SA.

Effects of SA on bacterial cell wall. AKP activity was measured according to the manufacturer's protocols to assess the cell wall integrity (Beyotime Institute of Biotechnology). E. coli cells $\left(1 \times 10^{6} \mathrm{CFU} / \mathrm{ml}\right)$ were plated into a 6 -well plate and treated with SA; $50 \mu 1$ bacterial suspension was collected at various time intervals $(0,3,6,9,12$ and $24 \mathrm{~h})$ and centrifuged at $415 \mathrm{~g}$ for $3 \mathrm{~min}$ under $25^{\circ} \mathrm{C}$. The supernatant was mixed with $50 \mu 1$ para-nitrophenyl phosphate. After $10 \mathrm{~min}$, the reaction was terminated by adding $100 \mu \mathrm{l}$ stop buffer (Alkaline Phosphatase Assay Kit; Beyotime Institute of Biotechnology). The absorbance was analyzed with a microplate reader (SpectraMax M5; Molecular Devices, LLC). AKP activity was expressed as the OD value at $405 \mathrm{~nm}$.

Effects of SA on the bacterial cell membrane. The integrity of the bacterial membrane was monitored by measuring the levels of ATP, DNA and RNA. E. coli was sedimented at $415 \mathrm{x} \mathrm{g}$ for $3 \mathrm{~min}$ under $25^{\circ} \mathrm{C}$ and washed two times with distilled water, and then resuspended into $3.6 \mathrm{ml}$ distilled water $\left(1 \times 10^{6} \mathrm{CFU} / \mathrm{ml}\right)$ prior to transfer into a 24 -well plate. Subsequently, SA (200 or $400 \mu \mathrm{M})$ was added and cells were incubated at $35^{\circ} \mathrm{C}$. At predetermined sampling times $(0,0.5$, $1,1.5$ and $2 \mathrm{~h}$ ), the bacterial suspension was centrifuged at $415 \mathrm{~g}$ and $25^{\circ} \mathrm{C}$ for $3 \mathrm{~min}$. A total of $50 \mu \mathrm{l}$ supernatant was mixed with $100 \mu 1$ ATP detection buffer (ATP Assay Kit; Beyotime Institute of Biotechnology). The luminous intensity was detected within $10 \mathrm{~min}$ by a microplate reader (Spectramax M5; Molecular Devices, LLC). The concentrations of DNA and RNA were measured in another experimental system. Briefly, following two washes with PBS, E. coli cells $\left(1 \times 10^{6} \mathrm{CFU} / \mathrm{ml}\right)$ were plated into a 24 -well plate and cultured with $\mathrm{SA}$ at $35^{\circ} \mathrm{C}$. At various time intervals $(0$, 2, 4, 6 and $8 \mathrm{~h}$ ), $100 \mu \mathrm{l}$ bacterial suspension was collected and centrifuged at $415 \mathrm{~g}$ and $25^{\circ} \mathrm{C}$ for $3 \mathrm{~min}$. The absorbance was determined at $260 \mathrm{~nm}$ using a microplate reader (SpectraMax M5; Molecular Devices, LLC). 
Effects of SA on protein expression. E. coli $\left(1 \times 10^{6} \mathrm{CFU} / \mathrm{ml}\right)$ were incubated with 200 or $400 \mu \mathrm{M} \mathrm{SA}$ in TSB medium for 24 and $32 \mathrm{~h}$, respectively, then centrifuged and washed twice with normal saline. The bacterial suspensions were evenly divided into two portions: One part was mixed with $400 \mu$ l distilled water and the other mixed with RIPA lysis buffer (Solarbio Science \& Technology Co., Ltd.). Following determination of the protein content by a BCA assay, the aqueous solution and lysate were separately mixed with 5X SDS and boiled for $5 \mathrm{~min}$ at $100^{\circ} \mathrm{C}$. Equal amounts of proteins $(1 \mu \mathrm{g})$ were separated via SDS-PAGE (10\% separating gel $/ 5 \%$ stacking gel) at $100 \mathrm{~V}$ for $1.5 \mathrm{~h}$. Then, the gels were stained with Coomassie Brilliant Blue overnight at $25^{\circ} \mathrm{C}$. Subsequently, the gels were de-stained in water for two days. The effects of SA on E. coli protein expression were analyzed according to the staining intensity of the protein bands.

Scanning electron microscopy (SEM). SEM was used to examine the morphology of E. coli cells. Following culture in fresh TSB medium with 200 or $400 \mu \mathrm{M} \mathrm{SA}$ for $20 \mathrm{~h}$ at $35^{\circ} \mathrm{C}$, the bacterial suspensions were centrifuged at $415 \mathrm{x}$ g for $10 \mathrm{~min}$ under $25^{\circ} \mathrm{C}$ and washed twice with PBS. E. coli was fixed in $5 \%$ glutaraldehyde for $4 \mathrm{~h}$ at $4^{\circ} \mathrm{C}$ in the dark. Following three washes with PBS, all samples were dehydrated once with 30 , $50,70,80$ and $90 \%$ ethanol, twice with $100 \%$ ethanol, each for $15 \mathrm{~min}$. Then, the samples were centrifuged at $2,771 \mathrm{x} \mathrm{g}$ for $3 \mathrm{~min}$ at $25^{\circ} \mathrm{C}$. Finally, all samples were sputter-coated with platinum prior to analysis with a scanning electron microscope (magnification, x10,000; SUPRA 55-VP; Carl Zeiss AG).

Transmission electron microscopy (TEM). To prepare samples for TEM, E. coli was cultured in TSB medium overnight and treated with 200 or $400 \mu \mathrm{M} \mathrm{SA}$ for $24 \mathrm{~h}$ at $35^{\circ} \mathrm{C}$. Untreated and SA-treated bacteria were harvested by centrifugation at $415 \mathrm{x} \mathrm{g}$ and $25^{\circ} \mathrm{C}$. Colonies of bacteria were fixed with $2.5 \%$ glutaraldehyde and $1 \% \mathrm{OsO}_{4}$ fixative solution $(\mathrm{pH} 7.4)$ for $4 \mathrm{~h}$ at $4^{\circ} \mathrm{C}$, and then rinsed with PBS. The samples were dehydrated with increasing concentrations of ethanol $(30,50$, $70,80,90$ and $100 \%$ ). Following drying for $24 \mathrm{~h}$, the samples were serially sectioned for TEM analysis at a magnification of x60,000. Ultrathin sections $(50 \mathrm{~nm})$ were visualized using a transmission electron microscope (1200 EX; JEOL, Ltd. pan). Images were acquired using an AMT $2 \mathrm{k}$ CCD camera (Advanced Microscopy Techniques, Corp.) under standard conditions.

Statistical analysis. The antimicrobial experiments were conducted in triplicate. All data were expressed as the mean \pm standard deviation and analyzed by one-way ANOVA followed by Dunnett's test using SPSS software (version 17.0; SPSS, Inc., Chicago, IL, USA). $\mathrm{P}<0.05$ was considered to significant to indicate a statistically significant difference.

\section{Results}

Antimicrobial activity of $S A$. The antimicrobial activity of SA against $E$. coli was analyzed in the present study. The highest rate of growth inhibition of SA against E. coli was $32.74 \pm 0.058 \%$ at $200 \mu \mathrm{M}$ and $31.24 \pm 0.065 \%$ at $400 \mu \mathrm{M}$ (Fig. 1). Dose-dependent responses to 25 and $200 \mu \mathrm{M}$

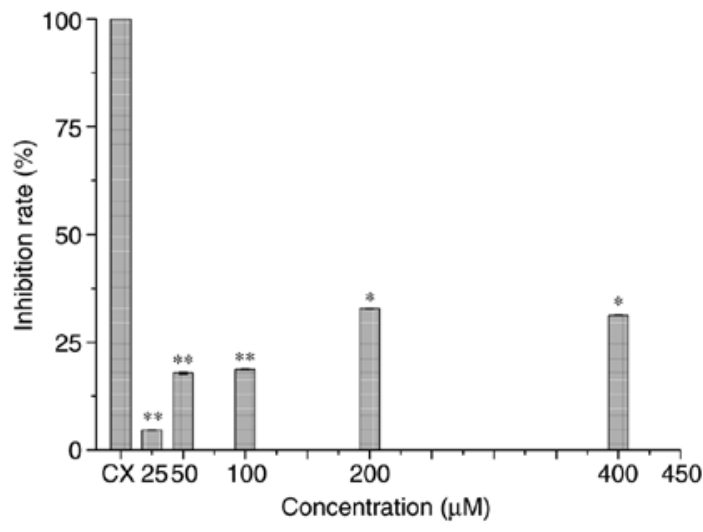

Figure 1. Antimicrobial activity of striatisporolide A against Escherichia coli ${ }^{*} \mathrm{P}<0.05,{ }^{* *} \mathrm{P}<0.01$ vs. CX group. $\mathrm{CX}$, ciprofloxacin hydrochloride.

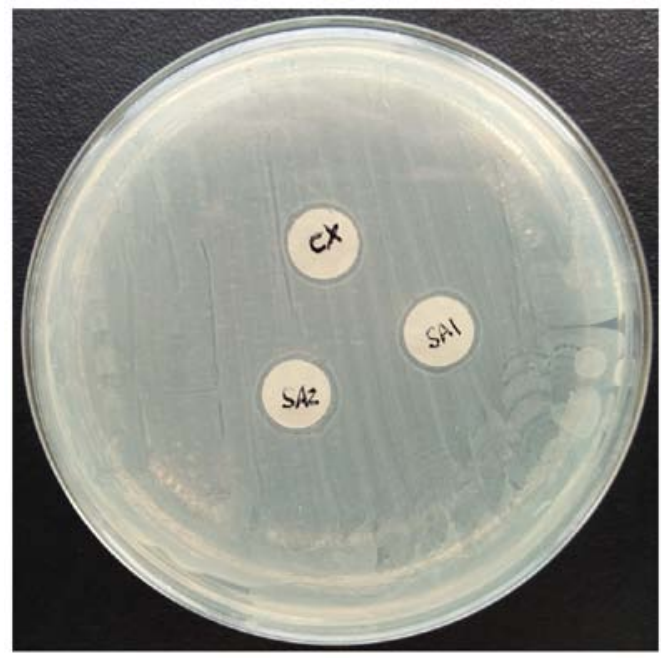

Figure 2. Inhibitory zones growth of Escherichia coli treated with SA1 and SA2, and CX. CX, ciprofloxacin hydrochloride; SA, striatisporolide A; $\mathrm{SA} 1,200 \mu \mathrm{M}$ SA; SA2, $400 \mu \mathrm{M}$ SA.

SA were observed. CX produced an increased inhibition rate of $100 \pm 0.07 \%$ against $E$. coli at $0.5 \mu \mathrm{g} / \mathrm{ml}$. Based on these findings, 200 (SA1) and $400 \mu \mathrm{M}$ (SA2) SA were used for subsequent analysis.

As presented in Fig. 2, E. coli exhibited low sensitivity to SA (200 and $400 \mu \mathrm{M})$ and $\mathrm{CX}(0.5 \mu \mathrm{g} / \mathrm{ml})$ according to the diameter of the inhibition zones $(7.03 \pm 0.04,7.08 \pm 0.06$ and $7.04 \pm 0.03 \mathrm{~mm}$, respectively), which was in accordance with the inhibitory rate of SA. There was no statistically significant difference in the inhibition zone diameters among the groups.

Effects of SA on bacterial cell wall. As presented in Fig. 3, SA notably increased the extracellular levels of AKP. In the normal group (NG), where the cells were treated with TSB medium alone, AKP activity was low. Following treatment with 200 and $400 \mu \mathrm{M} \mathrm{SA}$, the absorbance increased from 0.192 to $0.217 \pm 0.003$ and $0.192 \pm 0.001$ to $0.286 \pm 0.003$ at 3 and $24 \mathrm{~h}$, respectively. The activity of AKP exhibited peak values of $0.214 \pm 0.008$ and $0.299 \pm 0.002$ at $9 \mathrm{~h}$, which showed significant difference $(\mathrm{P}<0.01)$ compared with the normal group. In addition, SA at a concentration of $400 \mu \mathrm{M}$ exhibited 
a markedly stronger effect on the permeability of the $E$. coli cell wall than SA at $200 \mu \mathrm{M}(\mathrm{P}<0.05)$.

Effects of SA on the bacterial cell membrane. As presented in Fig. 4, the extracellular concentrations of ATP in the SA1 and SA2 groups were $0.83 \pm 0.08$ and $0.96 \pm 0.08 \mu \mathrm{M}$ at $0.5 \mathrm{~h}$, respectively, but decreased after 1 and $2 \mathrm{~h}$; which showed significant difference at $0.5(\mathrm{P}<0.01), 1$ and $2 \mathrm{~h}(\mathrm{P}<0.05)$ compared with the normal group; the ATP levels in the normal group were the same as that of the blank group, which were zero. These results indicated that SA may rapidly damage the cell membrane of E. coli and induce ATP leakage. In another experimental system, it was the DNA and RNA levels in the SA and the normal groups was determined. However, no changes in the DNA and RNA levels were observed between these groups.

Effects of SA on protein levels. Protein bands of 10 and $35 \mathrm{kDa}$ were observed following 10\% SDS-PAGE. Treatment with 200 and $400 \mu \mathrm{M}$ SA for 24 and $32 \mathrm{~h}$ notably increased the level of the $35 \mathrm{kDa}$ protein compared with the normal group in aqueous suspensions of bacteria (Fig. 5A). As presented Fig. 5B, SA notably reduced the level of the $10 \mathrm{kDa}$ protein in bacterial lysates. The results demonstrated that SA exhibited marked effects on protein levels in E. coli; however, there were no marked differences in the protein expression levels between 24 and $32 \mathrm{~h}$. Thus, SA may interfere in the protein metabolism within $24 \mathrm{~h}$.

SEM analysis. SEM was used to observe the morphological alterations of $E$. coli cells in the presence or absence of antibacterial treatments. Untreated $E$. coli exhibited a smooth and intact surface (Fig. 6A); the rod-shaped morphology of E. coli was retained. After $24 \mathrm{~h}$ of treatment with SA, the majority of the cells appeared to possess a rough surface, and the size of cells was irregular and shorter compared with the normal group (Fig. 6B and C).

TEM analysis. Similar to the results of SEM, TEM revealed that untreated $E$. coli cells appeared to exhibit typical cellular organization of Gram-negative bacteria (Fig. 7A); however, treatment with SA induced the alteration in the morphology of E. coli, including irregularities in the shape of the bacterium (Fig. 7B and $\mathrm{C}$ ).

\section{Discussion}

Butenolides are a class of lactones with a four-carbon heterocyclic ring structure, and possess important antibacterial, antiparasitic and antitumor properties. Evernic acid, an analogue of SA, severely inhibits the growth of Phytophthora infestans at $0.5 \times 10^{-5}-0.5 \times 10^{-3} \mathrm{M}$ (14). Methylenolactocin, an isomer of SA from Penicillium sp., has been reported to have prominent antibacterial activity against Gram-positive bacteria (15). Taibi et al (16) synthesized eight butenolide derivatives and revealed that three of these compounds exerted significant antimicrobial activity against $E$. coli. These findings suggest that butenolides have a wide range of antimicrobial targets and may be of potential use as bacterial agents; however, the exact antibacterial mechanism of these

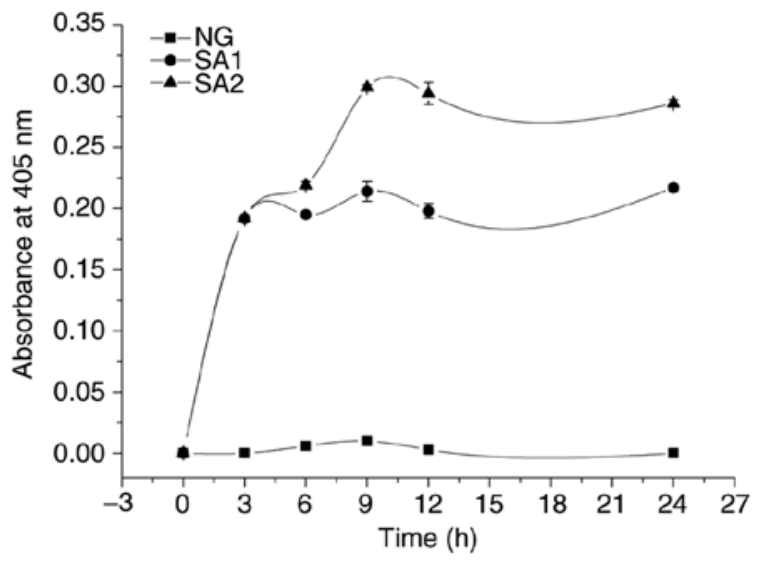

Figure 3. Effects of SA1 and SA2 on alkaline phosphatase activity in Escherichia coli. NG, Escherichia coli cells treated with TSB medium alone; SA, striatisporolide A; SA1, $200 \mu \mathrm{M} \mathrm{SA}$; SA2, $400 \mu \mathrm{M}$ SA.

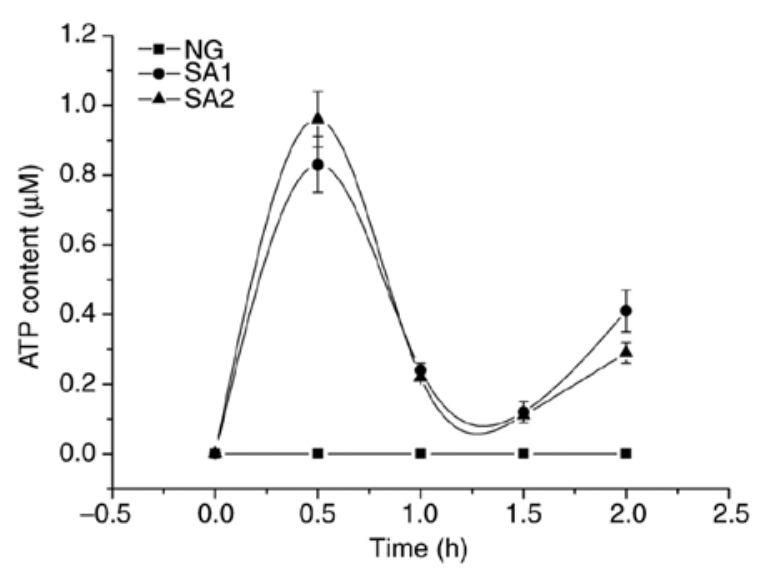

Figure 4. Effects of SA1 and SA2 on extracellular ATP content in Escherichia coli. NG, Escherichia coli cells treated with TSB medium alone; SA, striatisporolide A; SA1, $200 \mu \mathrm{M} \mathrm{SA}$; SA2, $400 \mu \mathrm{M} \mathrm{SA}$.

compounds is still unknown. The results of the present study suggested that SA had fewer antibacterial targets and weak activity compared with these compounds. It may be that structural variations are associated with the antibacterial potential of a compound.

In the current study, $\mathrm{CX}$ exhibited a high inhibitory rate at $0.5 \mu \mathrm{g} / \mathrm{ml}$; however, there appeared to be no difference in the inhibition zone diameter produced by CX and SA. We hypothesize that because the content of CX in the filter paper was much lower than that in the well of the 96-well microplate because the filter paper was just soaked in CX solvent $(0.5 \mu \mathrm{g} / \mathrm{ml})$ and then placed on the LB agar plate. Furthermore, CX was at a low concentration of $0.5 \mu \mathrm{g} / \mathrm{ml}$ and could not produce a larger inhibition zone in this diffusion state. Therefore, the difference in the inhibition zone diameter between CX and SA was not distinct.

AKP is present between the cell wall and cell membrane of bacteria, and may leak out of damaged cell walls; thus AKP is regarded as a marker of cell wall permeability (17). Diao et al (18) reported that the integrity of the Bacillus cereus cell wall could be disrupted by monolauroyl-galactosylglycerol, which led to leakage of AKP from the bacteria and into the extracellular environment. The results of the present study 

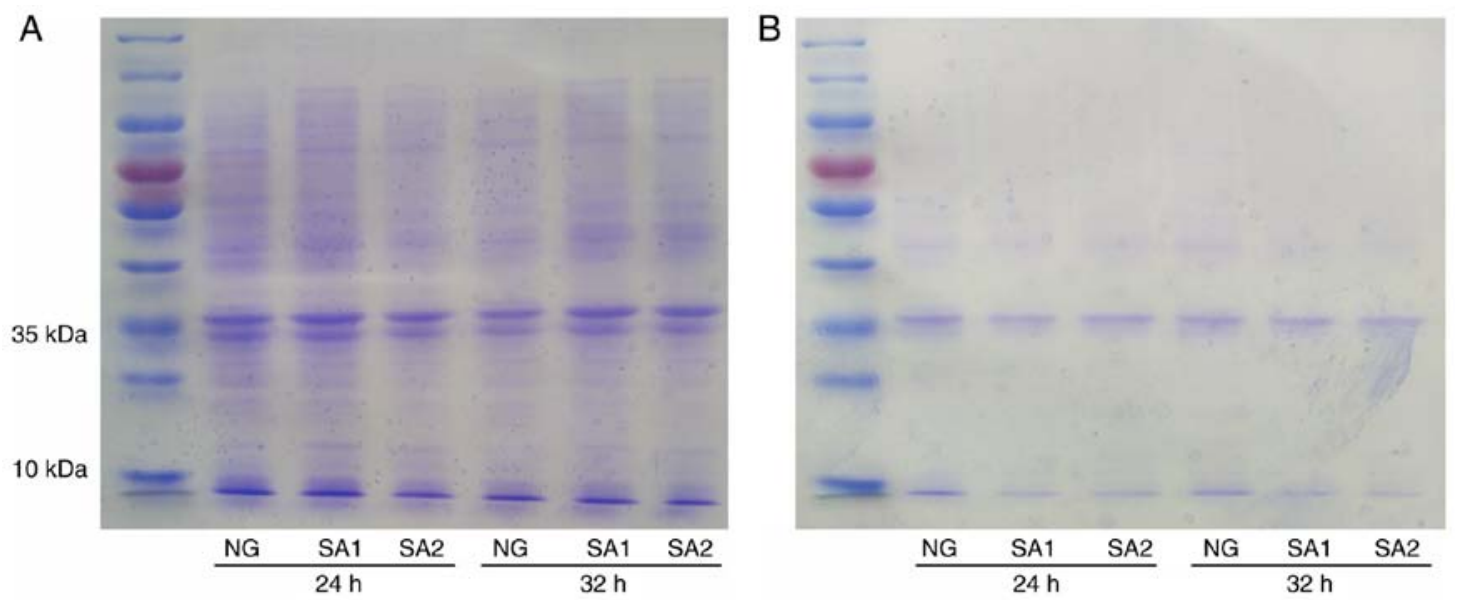

Figure 5. SDS-PAGE-based peptide mapping of Escherichia coli treated with SA1 and SA2. (A) Samples from an aqueous suspension of bacteria. (B) Samples from the bacterial lysate. NG, Escherichia coli cells treated with TSB medium; SA, striatisporolide A; SA1, $200 \mu \mathrm{M} \mathrm{SA}$; SA2, $400 \mu \mathrm{M}$ SA.
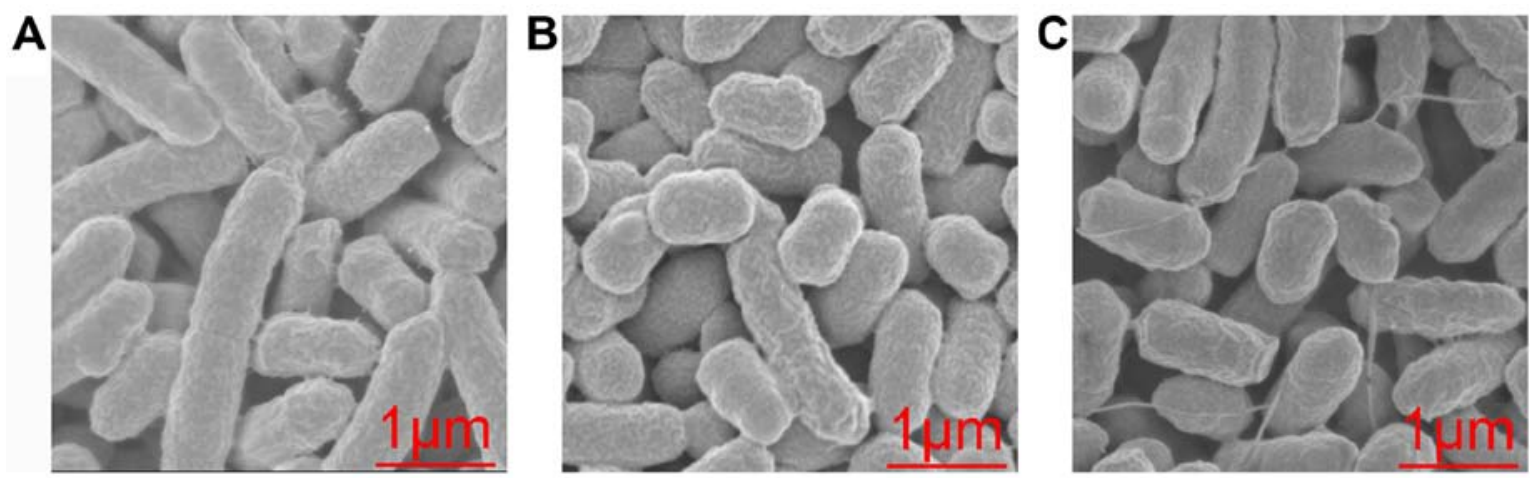

Figure 6. Scanning electron microscopy images of Escherichia coli cells treated (A) without SA, and with (B) $200 \mu \mathrm{M}$ and (C) $400 \mu \mathrm{M}$ SA. SA, striatisporolide A.
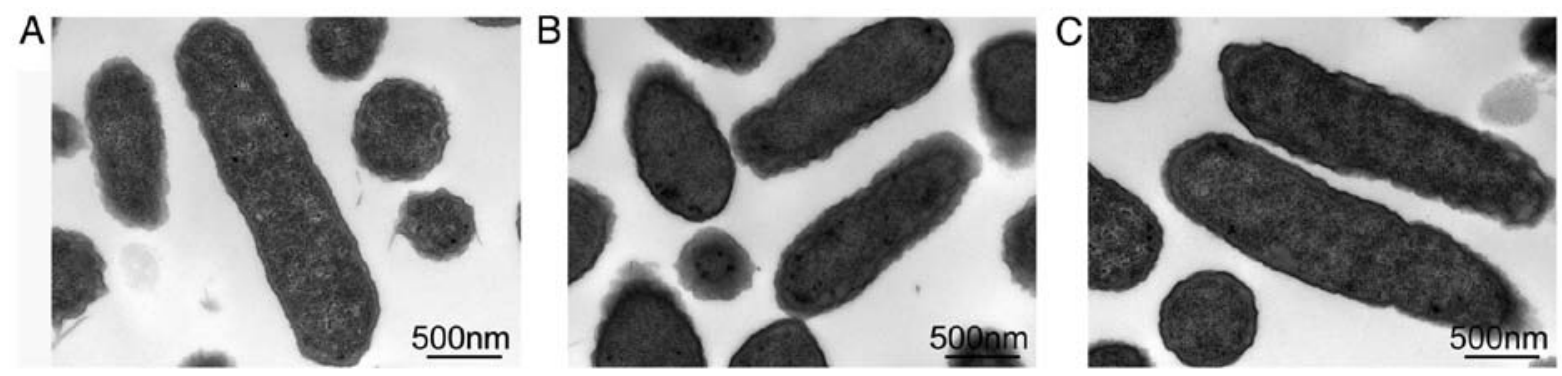

Figure 7. Transmission electron microscopy images of Escherichia coli cells treated (A) without SA, and with (B) $200 \mu \mathrm{M}$ and (C) $400 \mu \mathrm{M}$ SA. SA, striatisporolide A.

demonstrated that SA damaged the cell wall of $E$. coli and led to the leakage of AKP.

The leakage of cytoplasmic material has been associated with severe or irreversible damage to the cytoplasmic membrane; the levels of specific cell leakage markers, including ATP, nucleic acids and proteins, may be used to determine the integrity of the membrane (19). ATP is a complex biomolecule produced in all living organisms. It provides energy to drive all processes in living cells, including muscle contraction, the propagation of nerve impulses and chemical synthesis (20). ATP is an important index for interpreting the mechanisms of action of antimicrobial agents. The results from the present study suggested that the extracellular concentrations of ATP in the SA1 and SA2 groups increased from 0 to $0.5 \mathrm{~h}$, then decreased from 0.5 to $1.5 \mathrm{~h}$. As of the abnormal reductions in the levels of ATP, the present study proposed that damaged bacteria had undergone a process of self-repair, which inhibited the leakage of ATP from the damaged cell membrane induced by SA. In the other parallel experimental system, no notable leakage of DNA, RNA or protein was reported in the extracellular environment. Thus, it was proposed that SA-induced cell membrane damage may not cause leakage of the aforementioned molecules. It was previously reported that damage to the cell membrane of Enterobacter cloacae 
induced by $0.1 \% 3$-phenyllactic acid resulted in the leakage of low-molecular weight substances, such as ATP; however, the leakage of high-molecular weight substances, including nucleic acids and proteins were not detected (21). These findings were consistent with the observations of the present study.

Inhibition of bacterial protein synthesis is an important mechanism underlying the antibacterial properties of certain compounds. Wolf et al (22) reported that inhibition of protein synthesis by kirromycin occurred by blocking the release of elongation factor $\mathrm{Tu}$ from the ribosome following the enzymatic binding of aminoacyl-transferRNA and subsequent GTP hydrolysis. These findings suggest that SA may affect protein synthesis in E. coli; however, the underlying mechanism requires further investigation.

Damage to the cell wall and cell membrane can affect the permeability of these regions and lead to cell death (23). SEM indicated that SA-induced morphological alterations in E. coli may be responsible for the leakage of AKP and ATP, which serve pivotal roles in cell growth, proliferation and survival. Henning et al (24) reported that the antimicrobial effects of the nisin polypeptide occurred via interactions with the phospholipid components of the cytoplasmic membrane, which led to suppressed membrane function. The target site of SA on the cell wall and cell membrane of bacteria remains unknown; however, SA may penetrate cells and interact with intracellular substances due to its small molecular weight of $224 \mathrm{Da}$ and lipophilic structure (12). To further investigate the antibacterial mechanism, TEM analysis was conducted to observe ultrastructural alterations of the intracellular substances in E. coli.

ATP is an important precursor for DNA and RNA. It is required in RNA synthesis, and the replication and transcription of DNA. Therefore, the leakage of ATP may result in reduced levels of nucleic acids and ribosomes in E. coli, which may be involved in the antibacterial mechanism of SA. Antimicrobial agents can directly inhibit the synthesis and function of the intracellular biopolymers, such as proteins, DNA or ribosomes (25). Miao et al (26) reported that an antimicrobial peptide present in Tibetan kefir may inhibit the synthesis of $E$. coli DNA via direct interactions. These findings indicated that certain antimicrobial molecules may have numerous targets involved in eliminating bacteria. Furthermore, as SA has a low molecular weight and can penetrate bacteria, it may bind to bacterial DNA. A gel shift assay and AFM should be conducted in future to investigate the association between SA, DNA and protein.

The findings of the present study demonstrated the antibacterial activity of SA against $E$. coli. However, the highest reduction rate of the viable $E$. coli was only $32.74 \pm 0.058 \%$ by SA. Therefore, structural modifications of SA will be generated to explore the structure-activity relationships and improve its antibacterial activity in future experiments. The mechanisms of action of SA against $E$. coli, including how SA destroys the cell membrane and cell wall, regulates protein levels and abates nucleic acid levels in E. coli require further investigation.

In conclusion, the current study explored the antibacterial activity and the mechanism of SA for the first time. Although SA exhibited modest activity against $E$. coli, it did alter the protein level and damage the cell membrane and cell wall markedly, which provides an experimental basis for the antibacterial mechanism of butenolides. The present study proposed that SA may possess notable features as an effective and natural antibacterial agent.

\section{Acknowledgements}

Not applicable.

\section{Funding}

This work was supported by the National Natural Science Funds of China (nos. 81774125 and 81573717), the Natural Science Foundation of Shandong province (no. ZR2018LH017), the Project of Shandong Province Higher Educational Science and Technology Program (nos. J16LM04 and J17KB097) and Traditional Chinese Medicine Science and Technology Development Project of Shandong Province (no. 2017-205).

\section{Availability of data and materials}

The datasets used or analyzed during the current study are available from the corresponding author on reasonable request.

\section{Authors' contributions}

JWS designed this study and wrote the paper. DML, LJ and GXX performed the research. WFZ and JRJ checked and analyzed the data. JBT contributed to the acquisition of data, and critically revised the manuscript for important intellectual content.

\section{Ethics approval and consent to participate}

Not applicable.

\section{Patient consent for publication}

Not applicable.

\section{Competing interests}

The authors declare that they have no competing interests.

\section{References}

1. Hussein SH and Brasel JM: Toxicity, metabolism and impact of mycotoxins on human and animals. Toxicology 167: 101-134, 2001.

2. Tanvir R, Sajid I and Hasnain S: Screening of endophytic Streptomycetes isolated from Parthenium hysterophorus L. against nosocomial pathogens. Pak J Pharm Sci 26: 277-283, 2013.

3. Najjuka CF, Kateete DP, Kajumbula HM, Joloba ML and Essack SY: Antimicrobial susceptibility profiles of Escherichia coli and Klebsiella pneumoniae isolated from outpatients in urban and rural districts of Uganda. BMC Res Notes 9: 235, 2016.

4. Medina E and Pieper DH: Tackling threats and future problems of multidrug- resistant bacteria. Curr Top Microbiol Immunol 398: 3-33, 2016

5. Zaman SB, Hussain MA, Nye R, Mehta V, Mamun KT and Hossain N: A review on antibiotic resistance: Alarm bells are ringing. Cureus 9: e1403, 2017.

6. Lynda BC, Valérian F, Yohann C, Pierre L, Claire B, Jalloul B, Degraeve $\mathrm{P}$ and Oulahal N: Effect of interactions of plant phenolics with bovine meat proteins on their antibacterial activity. Food Control 90: 189-198, 2018.

7. Khan I and Oh DH: Integration of nisin into nanoparticles for application in foods. Innov Food Sci Emerg 34: 376-384, 2016. 
8. Sheng J and Sun Y: Antioxidant properties of different molecular weight polysaccharides from Athyrium multidentatum (Doll.) Ching. Carbohydr Polym 108: 41-45, 2014.

9. Liu DM, Sheng JW, Wang SH, Zhang WF, Zhang XH and Wang DY: Chemical constituents from Athyrium multidentatum (Doell.) Ching rhizome and their reducing power. Chin J Exp Trad Med Form 22: 185-188, 2016.

10. Stewart M, Capon RJ,Lacey E, Tennant S and Gill JH: Calbistrin E and two other new metabolites from an Australian isolate of Penicillium striatisporum. J Nat Prod 68: 581-584, 2005.

11. Liu DS, Huang YL, Ma LY, Lu CJ and Liu WZ: Chemical constituents and their cytotoxic activities of the secondary metabolites of Penicillium janthinellum. Chin Trad Patent Med 38: 830-834, 2016.

12. Liu DM, Sheng JW, Wang SH, Zhang WF, Zhang W and Zhang DJ: Cytoproliferative and cytoprotective effects of Striatisporolide A isolated from rhizomes of Athyrium multidentatum (Doell.) Ching on human umbilical vein endothelial cells. Molecules 21: 1280,2016

13. Mudzengi CP, Murwira A, Tivapasi M, Murungweni C, Burumu JV and Halimani T: Antibacterial activity of aqueous and methanol extracts of selected species used in livestock health management. Pharm Biol 55: 1054-1060, 2017.

14. Park BK, Nakagawa M, Hirota A and Nakayama M: Methylenolactocin, a novel antitumor antibiotic from Penicillium sp. J Antibiot (Tokyo) 41: 751-758, 1988.

15. Patrice $\mathrm{H}$ and Chantal VH: Antifungal activity of lichen extracts and lichenic acids. BioControl 49: 95-107, 2004

16. Taibi BH, Teffaha F and Ismail W: POM theoretical calculations and experimental verification of the antibacterial potential of 5-hydroxy-4-(substituted-amino)-2(5H)-furanones. Res Chem Intermediat 39: 1963-1971, 2013.

17. Xie J, Hou WF, Tang Y and Lan WQ: Antimicrobial mechanisms of phytic acid against Shewanella putrefacens. Sci Tech Food Indust 32: 85-88, 2011.

18. Diao M, Qi D, Xu M, Lu Z, Lv F, Bie X, Zhang C and Zhao H: Antibacterial activity and mechanism of monolauroyl-galactosylglycerol against Bacillus cereus. Food Control 85: 339-344, 2018.
19. Bajpai VK, Sharma A and Baek KH: Antibacterial mode of action of Cudrania tricuspidata fruit essential oil, affecting membrane permeability and surface characteristics of food-borne pathogens. Food Control 32: 582-590, 2013.

20. Rajendran M, Dane E, Conley J and Tantama M: Imaging adenosine triphosphate (ATP). Biol Bull 231: 73-84, 2016.

21. Liu F, Wang F, Du L, Zhao T, Doyle MP, Wang D, Zhang X, Sun Z and $\mathrm{Xu} \mathrm{W}$ : Antibacterial and antibiofilm activity of phenyllactic acid against Enterobacter cloacae. Food Control 84: 442-448, 2018.

22. Wolf H, Chinali G and Parmeggiani A: Mechanism of the inhibition of protein synthesis by kirromycin. Role of elongation factor Tu and ribosome. Eur J Biochem 75: 67-75, 1977.

23. Hameed AS, Karthikeyan C, Ahamed AP, Thajuddin N, Alharbi NS, Alharbi SA and Ravi G: In vitro antibacterial activity of $\mathrm{ZnO}$ and $\mathrm{Nd}$ doped $\mathrm{ZnO}$ nanoparticles against ESBL producing Escherichia coli and Klebsiella pneumoniae. Sci Rep 6: 24312, 2016.

24. Henning S, Metz R and Hammes WP: Studies on the mode of action of nisin. Int J Food Microbiol 3: 121-134, 1986.

25. Patrzykat A,Friedrich CL,Zhang L, Mendoza V and Hancock RE: Sublethal concentrations of pleurocidin-derived antimicrobial peptides inhibit macromolecular synthesis in Escherichia coli. Antimicrob Agents Chemother 46: 605-614, 2002.

26. Miao JY, Liu G, Ke C, Fan W, Li C, Chen Y, Dixon W, Song M, Cao Y and Xiao H: Inhibitory effects of a novel antimicrobial peptide from kefir against Escherichia coli. Food Control 65: 63-72, 2016.

This work is licensed under a Creative Commons Attribution-NonCommercial-NoDerivatives 4.0 International (CC BY-NC-ND 4.0) License. 